\title{
Jathil Lanang Performance in Ponorogo Regency
}

\author{
Slamet MD. , SD. Nur Ilham Brillian \\ Department of Dance, Faculty of Performing Arts, Institut Seni Indonesia Surakarta \\ Jl. Ki Hajar Dewantara 19 Kentingan, Jebres, Surakarta, Indonesia 57126
}

\begin{abstract}
Jathil Lanang dance was one of the developments in Reyog performance. Jathil Lanang was an interesting topic to be researched because it was a Jathil dance like in the past which was now being staged again. It aimed to show the public what Jathil was like before it changed to what it was now. This research used a qualitative method. The theory used was the concept of Y. Sumandiyo Hadi and the concept of Rhodes. The research data collection stage included observation, interviews, literature study as well as the data processing, and data analysis stages. Results of this study described Jathil Lanang's choreography, the elements contained in the choreography, and Sudirman's creativity as a choreographer.
\end{abstract}

Keywords: choreography, Jathil Lanang, Ponorogo, dance.

DOI: $10.7176 / \mathrm{ADS} / 87-02$

Publication date: November $30^{\text {th }} 2020$

\section{Introduction}

Ponorogo Regency was an area located in East Java Province which was known as the Town of Reyog or Bumi Reyog. The nickname had an explanation, because Ponorogo was the area where the Reyog Ponorogo folk performances originated. There were a variety of interesting performances that were still being performed in Ponorogo, but people still recognized Ponorogo from Reyog performances. According to Hartono, the word Reyog came from the word 'rog' which was the same as 'reg' that was meant 'erog, herog, horeg'. The word ' $o g$ ' was the same as $r o g$, then it became 'hoyog'. All of these words had the meaning to move or to shake. It was indicated that Reyog performance appeared at a time when the situation in Ponorogo was not peaceful (Hartono, 1980: 39).

Reyog performance with its agile dance always attracted attention. Until now, Reyog performance continued to develop and was increasingly recognized in the community. Reyog Ponorogo had attracted various circles of society including the Ponorogo community, local government, and academics (Simatupang, 2013: 117).

There was a Reyog performance in Ponorogo which was unique. The show was staged in an arena or in a house yard. The definition of a stage in this case was not in the form of a place that was higher in position than the ground, but rather as a place where the performance was held. The stage was deliberately made level with the ground in order to accommodate the dancers' agile movements.

Reyog was a folk show performed by a group of players with various characters and roles. Each Reyog performance featured the characters of Warok, Bujangganong, Klana Sewandana, Dadak Merak, and Jathil. Reyog performances that did not feature Klana Sewandana were usually called Reyog Obyog. Another difference was in Jathil dance.

Jathil was a folk dance performed in groups and always equipped with woven bamboo slats in the shape of a horse (Pigeaud, 1983: 265-266). At first Reyog performance in Ponorogo only featured Jathil Obyog. Jathil Obyog's movements were repeated continuously and were monotonous and only accentuated the shaking and twisting movements according to the rhythm. In subsequent developments, Jathil Lanang was performed as entertainment in Reyog performance. Jathil Lanang was actually not a new dance in Reyog. Since the first time Reyog was held, Jathil Lanang had been around.

Jathil Lanang, which was part of Reyog performance structure, a form of Reyog artists' creativity. The presence of Jathil Lanang in the show gave a new touch to the local community. This was because so far the majority of Reyog groups only presented Reyog with Jathil Obyog or female Jathil. Jathil Lanang was performed for the younger generation who had never seen Jathil Lanang dance at all and the older generation who longed for Jathil's performance as they had seen when they were young. Jathil Lanang emerged as a response to the shift in people's tastes who wanted an innovation in Reyog performance structure. Jathil Lanang was performed again because of Sudirman's role as choreographer. Sudirman's experience as a Jathil Lanang dancer since he was twelve years old was poured into Jathil Lanang choreography.

Jathil Lanang dance was dominated by movements depicting twin warriors having fun on horses. Besides that, there were Jathil Lanang movements which were composed of motion motifs, connection moves, and repetitive moves.

This research focused on Sudirman's choreography and creativity in composing Jathil Lanang. The problem could be described as followed: how was Jathil Lanang's choreography in Reyog performance? How was Sudirman's creativity in composing Jathil Lanang? The problems above required several concepts or theories as 
a basis in the discussion of problems related to choreography and creativity.

A choreography could not be separated from dance elements. The explanation of Jathil Lanang choreography concept used the concept of Y. Sumandiyo Hadi, that in a choreography there were elements including: 1) dance moves; (2) dancing space; (3) dance accompaniment/music; (4) dance title; (5) dance themes; (6) type/kind/nature of dance; (7) mode (of presentation; (8) lighting; (9) dancers (10) make up and dance costumes (11) equipment and accessories (Hadi, 2003: 23-95).

Jathil Lanang choreography could not be separated from Sudirman's role as a choreographer. The discussion on creativity used the Rhodes concept and concluded that in general, creativity had four types of dimensions that were used as the concept of creativity, namely 4P (Four P's Creativity). This concept included the dimensions of person, process, product, and press. Creativity in the dimension of person was an effort to identify creativity that focused on individuals who could be called creative. Creativity in the dimension of process was creativity that focused on the thought process so as to generate unique or creative ideas. Creativity in the dimension of press was a pressing creativity. In the press or push factor, both internal self-encouragement was in the form of a desire to create or engage in creative self, as well as external encouragement from social and psychological environment. Creativity in the dimension of product was a creativity effort that focused on products or what was produced by individuals, in the form of new or original things, or an innovative combination and creativity that focused on creative products emphasizing on originality (Munandar, 2002: 25).

The theories and concepts above were a basis for thinking to answer the problems in this research. Opinions were examined effectively, then they would be used for elaboration in the discussion of phenomena related to choreography and creativity in composing Jathil Lanang.

\section{The background of Jathil Lanang}

Jathil Lanang was different from Jathil dance in general. Not only because it was danced by men, but the movements that were performed were also different. Jathil dance could be performed by men or transvestites, but usually they only danced Jathil Obyog not Jathil Lanang. Jathil Lanang movement depicted the agility of a soldier who was training on a horse. Accompanied by musical instruments in the form of slompret (traditional bugle), kendhang, ketipung, angklung, kethuk, and kempul (a set of traditional percussions).

Jathil dance had been around since the first Reyog folk performance were created, the difference was that in the past, Jathil was danced by men or known as gemblak (Sudirman, interview, 19 October 2017). The costumes and make-up worn by Jathil Lanang dancers tended to resemble women's clothes, the dance movements also tended to be feminine, lively, and flirtatious. Jathil Lanang in Reyog performance today was no longer called gemblak like in the past, because gemblak was no longer exist. The existence of Jathil Lanang was solely for performance purposes, so that the existence of Jathil Lanang dance did not extinct due to changing times.

Reyog was originally created in Ponorogo before the 1980s and the ones who became Jathil dancers were gemblak. It was strengthened by a statement from Soetaryo's in a Miniggu newspaper article, September 11, 1960 written by Muhammad Zamzam Fauzanafi.

"Usually there are two children who ride on the horse, dressed in female traditional dance costumes, they dance behind the lions. The child must be chosen with a handsome face. Of course, those who ride the woven bamboo slats in a shape of a horses are the village's 'gemblakan'."(2005: 126)

Before the 1980s, Jathil dancers were always associated with the gemblakan tradition. Gemblak was a teenager who became warok's lover. Regarding the male Jathil dancer, Poerwowijoyo (1985: 3) in the first volume of his book Babad Ponorogo wrote.

"The boy who become the horse-riding dancer is about ten years old. The oldest is seventeen years old. They are called Jathil or Gemblakan." (Babad Ponorogo volume 1, 195: 3)

The description above elaborated the role og gemblak or Jathil dancers in ancient times. Gemblak kept by warok usually came from poor families. Parents purposely sent their children to warok to get education, because commoners in ancient times had almost imposibility getting an education. Only the rich could go to school. The necessities of life for gemblak were financed by the warok. They were also trained in folk arts by becoming Jathil dancers. According to Hariadi, gemblak that was kept by warok was schooled, taught farming, raising livestock, and being taught to perform folk arts (Hariadi, interview, 14 October 2017).

In the 1980s in Ponorogo, the existence of gemblak or Jathil Lanang was starting to become rare. Sudirman as a Jathil Lanang dancer said that since 1975-1976, in Ponorogo there had been many elementary schools established based on instructions from the president, so that children could more easily get education. This had led to the abandonment of gemblak tradition by Ponorogo community (Sudirman, interview, 15 October 2017). Since then, there were rarely Jathil Lanang or gemblak dancers in Ponorogo. Gemblak was no longer in demand among the community, because access to education was opened. Another reason was because boys were shy about being Jathil dancers. They thought that the dance was too flirtatious like a female dance. There was another opinion behind the extinction of gemblak, that the practice of gemblakan was considered indecent for Indonesia's moral standard and was not in line with Indonesian culture. The community considered gemblak to 
be a young man who belonged to warok. Gemblak's duty was to serve warok in satisfying their sexual desire.

Jathil Lanang, which was danced by gemblak, was later replaced by female dancers. The reyog artists, especially warok, rejected the replacement. Warok did not agree when gemblak was replaced by female dancers. The reason for not agreeing was because Reyog Ponorogo performance was a folk show inherited from the ancestors of the Ponorogo community, with a form of performance played by men. So to change dancers to women is inappropriate because if Jathil was danced by women, then the cavalry was less manly so that it would affect the Reyog performance (Sudirman, interview, 20 October 2017). Meanwhile, some people supported replacing gemblak with female Jathil dancers because the community wanted Reyog performance to be sustained in Ponorogo.

\section{The Choreography of Jathil Lanang}

Choreography came from the Greek language, namely chorea which means dance together and graphia which meant writing (Sal Murgiyanto, 1992: 9). The Jathil Lanang dance in Reyog show is a choreography that had several shaping elements in it. A form of choreography could not be separated from various dance elements. The explanation of the concept of Jathil Lanang's choreography used the concept from Y. Sumandiyo Hadi that in a choreography consisted of elements including: dance motions, dancing space, dance accompaniment/music, dance title, dance themes, type/kind/character of dance, mode of presentation, lighting, dancers, make up and dance costumes, equipment and accessories (Hadi, 2003: 23-95).

\subsection{Dance Motions}

Motion was the main medium in expressing one's soul. Dance was an expression of human soul which was shown by beautiful rhythmic movements (Soedarsono, 1978: 16). The movements of Jathil Lanang dance performed by dancers were basically a form of folk dance. The expression of Jathil Lanang movement was free without any binding rules. The movements in this dance did not have a special meaning but only mimic the movements of a soldier who was having fun on a horse. Dance movements included motion motifs, which were then divided into connecting movements and repetitive movements. The motifs for Jathil Lanang's movements used were: sembahan, junjungan, lawung, edrek, kipat srisig, lumaksana jeglongan, ukel karno, ukel wolakwalik tangan, mususi, keplok setan, congklangan, colotan, sarukan, engkling, ceklekan, sabetan, egolan, ogekan, and lumaksana panaragan.

\subsection{Dancing Space}

There were two definitions of dancing space, namely the stage and space for movement. The stage was a place that was used for performances, while the space for movement was a space formed due to movements made by the dancer. Space could be divided into several parts, namely the space that arised from motion motifs, levels, formations, and floor directions or patterns (Hadi, 2003: 23-27).

So far, Jathil Lanang dance had always performed in a wide area such as an open field. The venue was in the form of an arena stage so that the audience could watch from all directions. Jathil Lanang was a folk dance performance which in its show the audience gathered into one, there was no barrier between the audience and the dancers so as to provide an atmosphere of intimacy.

The dancing space emerged from the movement motifs in Jathil Lanang dance performed by dancers. The movements in the Jathil Lanang dance used small, moderate, and large volumes. The large movement volume was found in the motifs of sembahan, junjungan, and engkling. Moderate movement volume was found in the motifs of ceklekan, sabetan, egolan, kipat, srisig, ukel wolak-walik, lumaksana jeglongan, and lumaksana panaragan. Meanwhile, small movement volume could be found in the motifs of lawung, edrek, ukel karno, mususi, keplok setan, congklangan, colotan, and sarukan.

The dancing space in Jathil Lanang dance could also be seen in its formations or positions. The formation applied could be observed from the direction of the circular floor pattern, straight lines forward, backward, and sideways. Changing positions in Jathil Lanang using steps and srisig.

\subsection{Dance Music}

Dance performances could not be separated from the music accompaniment. In this case, dance and music were closely related and interconnected. The function of music as a dance accompaniment included guarding the rhythm of dance movements, supporting the dance atmosphere, so that there was a harmonious combination between the two (Hadi, 2003: 52). Reyog musical accompaniment had existed since ancient times, with the accompaniment of a set of kendhang, slompret, ketipung, angklung, kethuk, and kempul. Slompret in the Reyog performance had a pelog tune which has the function of being a song or melody carrier and giving a signal before another gamelan (traditional musical instrument) was played. Angklung had a function as a conducting sound, the tune used was pelog. Kendhang functioned to provide a signal when the song started, as a dance accompaniment, as a rhythm controller, and as a tempo regulator. Ketipung functioned to make the piece 
sounded more festive by sounding it between kethuk and kenong. Kethuk and kenong in Reyog music accompaniment was in pelog tune. They were beat alternately with a monotonous rhythm. Kempul had a slendro tune, beaten together with kethuk on an even number count.

In subsequent developments, Jathilan dance was accompanied by a piece of obyog gendhing (music), accompanied by a piece of panaragan as the opening. Currently, Jathilan dance was accompanied by three kinds of accompaniment pieces, namely Gendhing Sampak and Gendhing Obyog, with Gendhing Panaragan as the opening accompaniment.

\subsection{Dance Title}

The title was a tetenger or initial sign and was usually related to the theme of the dance (Hadi, 2003: 88). Jathil was a dance depicting twin warriors riding horses, while lanang meant male. According to Sudirman, the name for the Jathil dance that was danced by men was Jathil Lanang (Sudirman, 19 November 2017).

\subsection{Dance Theme}

In the Great Indonesia Dictionary 'tema/theme' was defined as the basis of the story (1988: 1164). The theme of dance could be understood as a subject matter that contained certain content or meaning from a choreography, both literal and non-literal (Hadi, 2003: 89). Jathil dance was a warrior-themed dance, manifested in a costume that resembled a soldier on a horse. In terms of costumes, the theme of warrior was taken because the costumes were like soldiers, while the movements were considered feminine because the dance movements were not always tough. Sometimes it was danced with slow and flirtatious movements. This was because Jathil was a form of Ki Ageng Kutu Suryangalam's allusion to the weakness of Majapahit warriors during the reign of Bhre Kertabhumi which was depicted as a feminine horseman (Simatupang, 2013: 119). Based on the theme created, the composition of Jathil Lanang dance movements was included in the non-literary dance composition, namely the dance composition that was worked out with the aim of conveying a message. Served like a story.

\subsection{The type/kind/character of dance}

Jathil Lanang was a type of traditional folk dance. Jathil Lanang was born, grew, and developed since ancient times among the common people, not within the palace walls. Folk dance performances were usually staged with simple dance movements, there were no standard limiting rules.

\subsection{Mode of presentation}

The mode of presentation in question was how the movements of the Jathil Lanang were presented. According to Y. Sumandiyo Hadi, the presentation mode could be divided into two very different presentations, namely representational and symbolic presentations (Hadi, 2003: 90). Jathil Lanang was categorized as a dance with representational symbolic presentation mode, which was a combination of the two modes.

\section{3,8. Lighting}

Jathil Lanang dance in Reyog performance did not really emphasize lighting. Lighting was usually only needed when performing at night, while Reyog performances were more often done during the day. If lighting was needed, the performer usually used a lamp that functioned as general lighting.

\subsection{Dancers}

Dancers were figures who had an important role in a dance performance. Dancers played a major role in revealing the form and content of dance. Jathil Lanang in Reyog performance was presented by two dancers. There were two dancers because Jathil dance was a depiction of twin horsemen. So in essence, regardless of the number of participants shown, the most important thing was that it was an even number. Jathil Lanang dancers in Reyog performance were male, according to the , Jathil Lanang which meant male Jathil.

\subsection{Dance Make Up and Costumes}

Make-up and costumes had an important meaning in a folk dance performance, because these two components made a dancer's appearance stand out. Make-up and costumes supported the dance presentation and were an attraction to the audience. According to Sal Murgiyanto, make-up was needed in a show to emphasize or accentuate the shape and lines of the face according to the dance character instructions (1992: 114). The makeup used by Jathil Lanang in Reyog performance was putra alus lanyap makeup according to the soldier character played. The dancers' eyebrows were firmly shaped, the sides of the face were drawn in the shape of sideburns. Jathilan dancers were not made up with mustaches because they represented warriors who acted like women. The costume worn by Jathil Lanang dancers featured the clothes of a soldier. One of the dancers was wearing a red kebaya and the other was wearing a yellow top. Jathil dancers also styled their hair in irah-irahan gelung keling for women, wear kepanjen trousers, pleated jarit (traditional cloth), and wear accessories, namely sampur 
in striking blue and pink colours, sash, kace necklaces, epek timang, bara samir, long socks and Lily slipper sandals.

\subsection{Equipments and Accessories}

Jathil lanang dancers used equipment in the form of eblek. Eblek was woven bamboo that was shaped like a horse, because basically Jathil dance was a depiction of a horse warrior. Eblek functioned as a horse.

\section{Sudirman's Creativity in Composing Jathil Lanang Dance}

Creative was the ability to discover or to create new things that had never existed before. Creative character existed because there was an urge in humans to create something. Creation could be done out of necessity or as a solution in solving a problem. Meanwhile, creativity was a process that involved the emergence of new ideas which were manifested in an action. Creativity could occur in various ways, including creativity in dance composing .

According to Rhodes' opinion quoted by Munandar, the definition of creativity was often referred to as Four P's Creativity: Person, Press, Process, Product (2002: 26). Creativity could be explained through personal, press, process, and product. Based on this explanation, Jathil Lanang dance composed by Sudirman was explained through the $4 \mathrm{P}$ concept.

\subsection{Person}

A personal figure would bring out a unique creativity. Sudirman as a choreographer was personally influenced by his talents, experience, and environment. The dance he created was based on personal experience that was influenced by social life today. Sudirman had the intelligence and ability to create and compose dances. Sudirman started studying arts, especially dance since he was a child. His desire to become a professional artist was a strong and very influential impetus in his personal development. Sudirman's personal development based on his experiences had made him a wiser person in dealing with cultural phenomena that occured. Sudirman did come from a family of artists. he himself had a love for the world of dance, especially Jathil. Sudirman was one of the choreographers who had great creativity and sensitivity to phenomena that occured in the environment. He was known as a productive choreographer, his experience in being a Jathil Lanang dancer was poured into the composition of Jathil Lanang dance.

\subsection{Press}

Motivation in bringing up creativity consisted of two factors, internal and external. This was the same as Munandar's opinion that the approach to creativity showed an emphasis on the press or push factor, both internal press, namely self-encouragement and external press from the social and psychological environment (Munandar, 2002: 23).

\subsubsection{Internal factor}

Internal factors were the pushing force that came from within a choreographer. Internal factors in composing Jathil Lanang dance were a strong desire which was influenced by factors that existed in Sudirman as a dancer, choreographer, and dance teacher, as well as his love for Reyog folk performances. The strong desire to become a professional choreographer and dancer was a driving factor within him. Sudirman's wish came true because of his hard work and persistence, supported by the dance skills he developed since he was a child. Sudirman's desire and abilities encouraged him to keep creating dances. Apart from the influence of the family, the educational environment and the community environment encouraged him to be creative. His education, which was specifically studying traditional performing arts and an art-filled environment that supported him, made it easier for him to carry out artistic and creative activities. His interest in dance could not be separated from Sudirman's experience when he was a dancer in a ceremony to welcome President Soeharto during his visit to Ponorogo. Since then, Sudirman had studied dance until now.

Based on the explanation above, the press factor within Sudirman in the form of a desire to preserve Jathil Lanang so that its existence did not extinct, was a task that must be accepted and carried out since joining warok and gemblak communities. Sudirman composed Jathil Lanang dance so that it could be introduced to generations of Reyog lovers, although in its development, it had to adapt to the community's wishes. Sudirman believed that with his strong abilities and efforts, he was able to develop his imagination which was translated into creative ideas and manifested in the form of a dance composition. Sudirman's creativity and ability to interpret were one of the pressing factors for interpreting stories or events, feelings, movements, which then became the insights needed in Jathil Lanang dance. The dance composition was based on Sudirman's personal experience in dealing with phenomena that occur in society.

\subsubsection{External Factor}

The external factor affecting Sudirman was a request from academics to bring back Jathil Lanang. Academics who conducted research on Jathil Lanang encouraged Sudirman to reconstruct the Jathil Lanang dance. 
Sudirman was appointed to do so because he was a Jathil dancer from the past who still existed today. This was the beginning of Jathil Lanang composing process. The phenomenon taken in this dance was Jathil Lanang or Jathil Gemblak. The reason for choosing this phenomenon was because at this time, Ponorogo people wanted to enjoy Jathil dance dance as it was in ancient times. Starting from there, Jathil Lanang dance was compiled with an idea that took the phenomena existed in Indonesian society. Sudirman's creativity did not only depend on his skills in the field of dance, but there was also motivation within him to express creativity.

\subsection{Process}

A choreographer's creative process started from within himself so that he could manifest the characteristics of the choreography. The process of arranging Jathil Lanang dance movements in Reyog performance was carried out by Sudirman as a choreographer. Sudirman used to be a Jathil Lanang dancer, meaning he had gone through the process of seeing, feeling, imagining, embodying, and shaping. Initially, Sudirman saw the material object of Jathil Lanang dance movement in ancient times, based on his experience when he was involved as a Jathil Lanang dancer. Sudirman followed the music accompaniment with full concentration and over time he felt an inner impulse that made him acquire his imagination. This process gave rise to the image of a feminine hussar dancing gracefully. The developing image evoked the leading impulse to be expressed. An essential aspect of self-discovery and formation process in dance was the liberation of the body and mind (Dibia, 2003: 28).

Sudirman's creative process started from seeing the phenomena that were around him, which meant that the problem posed was how the conditions of the phenomena around him were. In the end, Jathil Lanang dance was formed after experiencing several processes that could not be separated from Sudirman's creativity. Jathil Lanang dance was composed at a new level which was the result of communication among choreographer, surrounding environment, and phenomena around it.

The opinion of Alma Hawkins quoted by Sumandiyo Hadi was that to realize ideas, dance choreographers could go through several steps, namely exploration, improvisation, and composition. So was what Sudirman did as followed.

\subsubsection{Exploration}

The initial stage carried out by dance composers was exploration. Exploration included thinking, imagining, feeling, and responding (Hadi, 2003: 65). Sudirman explored all of his abilities and experiences related to Jathil Lanang that he had previously learned. As much as possible he composed Jathil Lanang dance which was exactly like the Jathil Lanang in the past, so that Sudirman did not make many changes.

\subsubsection{Improvisation}

Improvisation was defined as a spontaneous attempt to get new dance movements (Hadi, 2003: 70). Soedarsono said that improvisation when used wisely was a valuable way to increase creativity development (Soedarsono, 1987: 40). Based on the motion motifs obtained from the exploration process, Sudirman developed it again so that the dance became more interesting.

\subsubsection{Composition}

Composition was the stage after exploration and improvisation. Composition was an effort to arrange movements that form spontaneously regarding selection, integration, and unification (Soedarsono, 1978: 41). This stage was the last stage in the composing process. Composition was often referred to as the whole series of processes that choreographers carried out in composing dance. After Jathil Lanang dance movements were arranged, what was done next was to arrange Jathil Lanang dance movements of Reyog Cokro Menggolo performance group to make it looked more attractive. Sudirman considered two things, namely: the selection of motion content that had been obtained in exploration and improvisation process; and constructional motion arrangement which wiould give form as a whole.

\subsection{Product}

Product was the end result of a creative process. Product that was produced by Sudirman was Jathil Lanang dance. The definition of 'creative product' term was the element of originality and novelty of the dance. Jathil Lanang dance in Reyog performance composed by Sudirman used motion material from ancient Jathil Lanang. The dance material that had been learned by Sudirman when he was still in warok and gemblak community was rearranged according to current developments. Jathil Lanang dance was a creative product in which there was originality in the form of ideas that were realized based on Jathil Lanang phenomenon. It was understandable that combinations of pre-existing dances could be called a form of creativity after producing new dances that had never been composed or created before.

\section{The Formation of Jathil Lanang Motion Motifs}

Movement formation was a process that occured when a person performed a motion which was the initial part of composing a dance. Starting with the formation of motion motifs. The motion motifs as a dance formation was formed according to the needs, and was based on the floor trajectory. The motion patterns that formed motion 
motifs were composed based on the dancers movements. Jathil Lanang dance motifs formation could not be separated from motion, space, and time.

Dance design in terms of movement was a set of connection among action, effort, and space, where none of these aspects could exist without the other in the motif, but one or more got emphasized by the others (Suharto: 1985: 44). Effort: covered the theme and dynamics that gave rise to action or motion (Hutchinson, 1977: 11). The body action was adjusted to the theme of Jathil Lanang dance movement, namely the movement of warriors. The forms of action used include jumping, moving forward, moving backward, stretching the arms to the side, light arm swing, and trajectory (theme). Dynamics could be expressed in various ways including setting the stage level to high or low (space), changing the tempo (time), emphasizing from strong movements to soft movements (dynamics/power).

Dance design in terms of time was a tool to emphasize the strength connection of a series of movements, and also as a tool to develop in a sustainable manner, and to flow dynamically, so that the dance became more organized. The time structure in dance had aspects of tempo, rhythm, and duration (Hadi, 2003: 50). Dance accompaniment could be chosen by considering rhythm and tempo. In understanding the aspect of time, dance as a time design could not be separated from its music accompaniment. Music and dance were closely related. Both came from the same source, namely human rhythmic instincts and impulses. Music as a dance accompaniment could serve to strengthen dance expressions.

Dance design in terms of space (volume) was something that did not move and was stationary until the movements that occured in it used the time, and in this way embodied space as a form, a special expression related to the dynamic time of movement (Hadi, 2003). : 23). When composing Jathil Lanang dance movement, Sudirman paid attention to the movements that were present in the space so that the space that was built was constructive and attractive. Jathil Lanang dance movement presented by Sudirman used a space arranged with an elevated stage level to make it more attractive. The space for movement in Jathil Lanang dance, which was danced by two male dancers, was presented with the development and variation of action and effort from the motion contents in time and space using simultaneous harmony and front row neatness.

\section{Conclusion}

The object of this research was Sudirman's choreography and creativity in composing Jathil Lanang dance for Reyog performances. Jathil Lanang's choreography in Reyog performance consisted of dance elements, including dance movements, dancing space, dance accompaniment/ music, dance title, dance theme, type/kind/characteristics of dance, mode/method of presentation, lighting, dancers, make-up and dance costumes, equipment and accessories. Jathil Lanang's choreography was based on the creativity of the artist (choreographer). The idea that emerged during the compilation was inspired by Sudirman's personal experience as a choreographer and Jathil Lanang dancer. Sudirman's creativity in composing Jathil Lanang dance was explained through person, press, process, and product made. The person in question was Sudirman himself, including his talents, experience, and environment; press in this case was an encouragement or motivation that supported Sudirman in composing the choreography of Jathil Lanang including external and internal factors; the process of forming a choreography, which was an act of the body as a process of creation, including exploration, improvisation and composition; the product as the end result or the product that was produced was the Jathil Lanang choreography. The formation of movement motifs in Jathil Lanang dance could not be separated from motion, space, and time.

\section{References}

Alwi, Hasan dkk. Kamus Besar Bahasa Indonesia. Jakarta: Balai Pustaka, 2001/1998.

Hadi, Sumandyo. Aspek-Aspek Dasar Koreografi Kelompok. Yogyakarta: Lembaga Kajian Pendidikan dan Humaniora Indonesia, 2003.

Fauzannafi, Muhammad Zamzam. Reog Ponorogo: Menari Diantara Dominasi dan Keragaman. Yogyakarta: Kepel Press, 2005

Handayani T. \& Sugiarti. Konsep \& Teknik Penelitian Gender. Malang : UMM Press, 2008.

Hartono. Reog Ponorogo. Jakarta: Proyek Penulisan dan Penerbitan Buku/Majalah Pengetahuan Umum dan Profesi Departemen Pendidikan dan Kebudayaan, 1980.

Hawkins, Alma. Mencipta Lewat Tari (Creating Through Dance). Terjemahan Y. Sumandiyo Hadi. Yogyakarta: ISI Yogyakarta, 1990.

Bergerak Menurut Kata Hati. Terjemahan I Wayan Dibia. Jakarta: Ford Foundation dan Masyarakat Seni Pertunjukan Indonesia, 2003.

Langer, Suzane K. Problematika Seni. Terjemahan FX Widaryanto. Bandung: Sunan Ambu Press, 2006.

Mukarromah S. \& Devi S. I.S.R. "Mobilisasi Masa Partai Melalui Seni Pertunjukan Reog Di Ponorogo Tahun 1950-1980" dalam Jurnal Unair Verleden, Vol. 1, No. 1 Desember 2012: 1-109. 2012.

Munandar, Utami. "Kreativitas dan Keberbakatan”. Surakarta, 2002. 
Murgiyanto, Sal. Koreografi. Jakarta: Proyek Peningkatan Perbukuan Pendidikan Menengah, 1992. Tradisi dan Inovasi. Jakarta: Wedatama Widyasastra, 2004.

Nugroho, Riant. Gender dan Strategi Pengarus-Utamaannya Di Indonesia. Yogyakarta: Pustaka Pelajar, 2008 Poerwowijoyo. Babad Ponorogo Jilid I. Ponorogo: Depdikbud Kanwil, 1978.

Rohidi, Tjetjep Rohendi. 2000. Kesenian dalam Pendekatan Kebudayaan. Bandung: STSI press, 2000.

Sedyawati, Edi. Pertumbuhan Seni Pertunjukan. Jakarta: Sinar Harapan, 1981. . Pertumbuhan Seni Pertunjukan. Jakarta: Pustaka Jaya, 1984.

Budaya Indonesia: Kajian Arkeologi, Seni, dan Sejarah. Jakarta: Raja Grafindo Persada, 2006

Simatupang, Lono. Pergelaran: Sebuah Mozaik Penelitian Seni-Budaya. Yogyakarta: Jalasutra, 2013.

Slamet. Pengaruh Perkembangan Politik, Sosial, dan Ekonomi Terhadap Barongan Blora (1964-2009). Yogyakarta: Sekolah pascasarjana Universitas Gadjah Mada, 2010.

Smith, Jacqueline. Komposisi Tari Sebuah Petunjuk Praktis Bagi Guru. Terjemahan Ben Suharto. Yogykarta: Ikalasti, 1985.

Soedarsono. Pengantar Pengetahuan dan Komposisi Tari. Yogyakarta: Akademi Seni Tari Indonesia, 1978. Tari-Tarian Indonesia. Jakarta: Proyek Pengembangan Media Kebudayaan, Direktorat Jendral Kebudayaan, Departemen Pendidikan dan Kebudayaan, 1997.

Subagyo. Membangun Kesadaran Sejarah. Semarang: Widya Karya, 2003.

Informants

Sudirman. 53 year. Dance teacher and Reog artist. Jalan Pemuda 114 Paju Ponorogo.

Hariadi. 54 year. Dance teacher and Reog artist. Desa Pohijo, Kecamatan Sampung, Ponorogo. 